\title{
PENGARUH PENDIDIKAN KESEHATAN TANDA BAHAYA KEHAMILAN TERHADAP SIKAP IBU HAMIL TENTANG TANDA BAHAYA KEHAMILAN DI BPM Ny. FY Ds. PENATARAN NGLEGOK-BLITAR (The Effect of Health Education Danger Signs of Pregnancy Attitudes of Pregnant Women Danger Signs in Pregnancy BPM Ny. FY Penataran Village Nglegok-Blitar)
}

\author{
Lusi Erawati, Dina Zakiyyatul Fuadah, Widyasih Sunaringtyas \\ S1 Keperawatan, STIKES Karya Husada Kediri \\ email: dinazakiyya_ichsan@yahoo.co.id
}

\begin{abstract}
The dangerous signs of pregnancy is a sign that indicates a hazard that occurs during pregnancy or antenatal period which can cause maternal mortality if ureported or undetected. In order to decrease both mother and fetus mortality can be done by increasing knowledge of mother or family by providing health education. Objective: The research was to determine the effectiveness of health education about the dangerous sign of pregnancy toward pregnant woman's attitudes on the dangerous sign of pregnancy. Methods: The research design was Pre Experimental using one-group pre-post test design. The health education was done by using leaflets and powerpoint. The population was 90 pregnant women in BPM of Ny. Fy in Penataran, Nglegok, Blitar and the sample was 30 respondents by purposive sampling technique. Result: Wilcoxon test results obtained $\tilde{n}$ value $=(0.0001)<a ́=0.05$, which means $H \mathrm{H}$ was accepted, so that there was an effect of the dangerous sign of pregnancy toward pregnant woman's attitudes on the dangerous sign of pregnancy in BPM of Ny. Fy In Penataran, Nglegok, Blitar. Discussion: the successful of health education was determined by age and educational background. Age are in line with the responsibility for good attitude, the more age the more responsibility. The higher educational background, the more good response for stimulus from outside.
\end{abstract}

Keywords: health education, attitude, pregnant mother, danger sign pregnancy

\begin{abstract}
Abstrak: Tanda bahaya kehamilan adalah tanda yang mengindikasikan adanya bahaya yang terjadi selama kehamilan atau periode antenatal, yang apabila tidak terdeteksi bisa menyebabkan kematian ibu. Dalam upaya menurunkan angka kematian ibu maupun janin dilakukan dengan meningkatkan pengetahuan dengan memberikan pendidikan kesehatan. Tujuan Penelitian: mengetahui pengaruh pendidikan kesehatan tanda bahaya kehamilan terhadap sikap ibu hamil tentang tanda bahaya kehamilan. Metode: Desain penelitian Pre Eksperimen menggunakan one group pre-post test design. Pendidikan kesehatan dilakukan dengan media leaflet dan powerpoint. Populasi yang digunakan sebanyak 90 responden dan sampel 30 responden dengan teknik purposive sampling. Hasil: Uji Wilcoxon didapatkan $\rho$ value $=(0,0001)<\alpha=0,05$, bahwa $\mathrm{H} 1$ diterima, artinya terdapat pengaruh pendidikan kesehatan tanda bahaya kehamilan terhadap sikap ibu hamil tentang tanda bahaya kehamilan di BPM Ny. Fy Desa Penataran, Nglegok, Blitar. Diskusi: Keberhasilan pendidikan kesehatan dari faktor usia, tingkat pendidikan. Semakin bertambah usia seseorang semakin mengarahkan pada perwujudan sikap yang baik dan semakin tinggi tingkat pendidikan seseorang maka didapatkan respon yang baik terhadap stimulus dari luar. Kesimpulan: Pendidikan kesehatan efektif dalam meningkatkan sikap ibu hamil.
\end{abstract}

Kata Kunci: pendidikan kesehatan, sikap, ibu hamil, tanda bahaya kehamilan 
Kehamilan merupakan proses alamiah yang akan dialami oleh setiap wanita. Lama kehamilan sampai aterm adalah 280 sampai 300 hari atau 39-40 minggu, sehingga selama masa tersebut ibu hamil memerlukan pengawasan yang tepat (Manuaba, 2006). Pada awalnya kehamilan yang diperkirakan normal dapat berkembang menjadi kehamilan yang pathologi sehingga meningkatkan angka kematian pada ibu hamil. World Health Organization (WHO) tahun 2014 mendefinisikan kematian ibu adalah kematian seorang wanita yang terjadi saat hamil, bersalin atau 42 hari setelah persalinan dengan penyebab yang berhubungan langsung atau tidak langsung terhadap persalinan.

Angka kematian ibu masih merupakan masalah utama dalam bidang kesehatan, diperkirakan 800 perempuan meninggal setiap harinya akibat komplikasi kehamilan dan proses kelahiran. Angka Kematian Ibu (AKI) di Indonesia masih cukup tinggi, pada tahun 2012 mencapai 228 kasus per 100.000 kelahiran hidup, yang mana masih dibawah pencapaian target tahun 2014 yaitu 118 kasus per 100.000 kelahiran hidup (Dinkes, 2013). Kematian ibu terjadi pada perempuan yang terlalu muda dan terlalu tua untuk hamil, jarak kehamilan yang terlalu berdekatan, serta kehamilan yang terlalu sering. Selain itu terdapat beberapa kondisi lain seperti anemia usia 15 sampai 24 tahun masih tinggi yaitu sebesar 18,4\% (Riskesdas, 2013).

Di Jawa Timur terjadi 500 kematian atau 90 per 100.000 kelahiran hidup (Dinkes Jatim, 2010). Sedangkan di kabupaten Blitar tahun 2006 ada 10 kematian atau 57,7 per 100.000 kelahiran hidup cenderung meningkat bahkan tahun 2008 mencapai 17 kematian atau 99,67 per 100.000 kelahiran hidup dan tahun 2011 sampai bulan November sudah 16 kematian. Hal ini jauh dari target kabupaten yaitu 10 kematian atau 58/100.000 kelahiran hidup.

Berdasarkan studi pendahuluan yang telah dilakukan peneliti pada tanggal 10 Oktober 2015 di Desa Tumpang, Kecamatan Talun, Kabupaten Blitar pada 10 ibu hamil yang sudah dilakukan wawancara, didapatkan ada 3 ibu hamil yang mengetahui tanda bahaya kehamilan dan bersikap positif dalam menghadapi tanda bahaya kehamilan ditunjukkan dengan kesiapan dirinya ketika mengalami salah satu tanda bahaya kehamilan dengan periksa ke bidan yang ada di desanya, dan 7 ibu hamil tidak mengetahui tanda bahaya kehamilan dan bersikap negatif dalam menghadapi tanda bahaya kehamilan tersebut seperti cemas dan tidak tau apa yang seharusnya dilakukan (Erawati, 2015).
Angka kematian yang tinggi pada umumnya mempunyai tiga sebab pokok, yaitu masih kurangnya pengetahuan mengenai sebab pokok yaitu masih kurangnya pengetahuan mengenai sebab dan penanggulangan komplikasi-komplikasi penting dalam kehamilan, persalinan, serta nifas, kurangnya pengertian dan pengetahuan mengenai kesehatan reproduksi serta kurang meratanya pelayanan kebidanan yang baik bagi semua ibu hamil (Wiknjosastro, 2010). Menurut Varney (2007) di Negara-negara berkembang ada lima penyebab utama kematian ibu, diantaranya adalah perdarahan, sepsis, hipertensi akibat kehamilan, aborsi yang tidak aman dan persalinan macet. Penyebab tidak langsung kematian ibu antara lain kurang energy kronik/KEK pada kehamilan $(37 \%)$ dan anemia pada kehamilan $(40 \%)$.

Pengetahuan tentang tanda bahaya kehamilan merupakan hak yang penting untuk diketahui oleh masayarakat, khususnya bagi ibu hamil. Hal ini penting karena apabila seorang ibu hamil memiliki pengetahuan yang lebih tentang bahaya kehamilan maka kemungkinan besar ibu akan berpikir untuk menentukan sikap dan perilaku untuk mencegah, menghindari atau mengatasi bahaya kehamilan tersebut. Berkaitan dengan hal itu untuk meningkatkan pengetahuan ibu hamil mengenai tanda bahaya kehamilan diperlukan adanya pendidikan kesehatan yang dilakukan oleh tenaga kesehatan serta meningkatkan mutu dan terjangkaunya pelayanan kesehatan yang semakin merata salah satunya pemeriksaan Antenatal (Hasugian, 2012).

Hal ini juga didukung oleh progam pemerintah melalui komitmen bersama tentang tujuan pembanguan Milenium Development Goals (MDGs) pada tahun 2015, mengenai dua sasaran dan indikator yang terkait dengan kesehatan ibu dan anak yaitu mengurangi angka kematian ibu (AKI) dan bayi. Target $M D G s$ pada tahun 2015 yaitu menurunkan angka kematian ibu (AKI) sampai 124 per 100.000 kelahiran hidup (Yohanasari, 2011).

Memperhatikan kenyataan diatas, dalam rangka menurunkan angka kematian ibu sesuai target MDGs, maka perlu dilakukan pendidikan kesehatan mengenai tanda bahaya kehamilan guna meningkatkan pengetahuan ibu hamil serta sikap ibu hamil tentang tanda bahaya kehamilan. Pendidikan kesehatan ini sangat penting karena masih ada ibu hamil yang belum mengetahui tanda bahaya kehamilan.

Tujuan umum penelitian adalah Mengetahui pengaruh pendidikan kesehatan tanda bahaya 
kehamilan terhadap sikap ibu hamil tentandtanda bahaya kehamilandi BPM Ny. FY Desa Penataran Kecamatan Nglegok Kabupaten Blitar. Tujuan khusus (1) Mengidentifikasi sikap ibu hamil tentang tanda bahaya kehamilan sebelum diberikan pendidikan kesehatan (2) Mengidentifikasi sikap ibu hamil tentang tanda bahaya kehamilan setelah diberikan pendidikan kesehatan (3) Menganalisis pengaruh pendidikan kesehatan tentang tanda bahaya kehamilan terhadap sikap ibu hamil tentang tanda bahaya kehamilan di BPM Ny. FY Desa Penataran Kecamatan Nglegok Kabupaten Blitar.

Manfaat bagi perkembangan ilmu keperawatan yaitu Hasil penelitian ini dapat digunakan sebagai bahan masukan dalam upaya meningkatkan profesionalisme dan mutu pelayanan keperawatan, khususnya keperawatan maternitas.

\section{BAHAN DAN METODE}

Dalam penelitian ini peneliti menggunakan desain "Pre-Experimental". Penelitian dilakukan untuk mengetahui pengaruh pendidikan kesehatan tanda bahaya kehamilan terhadap sikap ibu hamil tentang tanda bahaya kehamilan di BPM Ny. FY Desa Penataran Kecamatan Nglegok Kabupaten Blitar. Jenis Pre-Experimental yang digunakan "one group pra-post test design" dengan cara penelitian yang dilakukan dengan memberikan pretest terlebih dahulu sebelum diberikan pendidikan kesehatan, setelah itu diberikan pendidikan kesehatan tentang tanda bahaya kehamilan, kemudian setelah dua minggu diberikan posttest. Sampel penelitian ini adalah 30 ibu hamil di BPM Ny. FY Desa Penataran Kecamatan Nglegok Kabupaten Blitar sebanyak 30 responden, dengan kriteria inklusi yaitu Ibu hamil yang kooperatif serta dapat membaca dan menulis, Ibu hamil yang berada di wilayah kerja BPM Desa Penataran Kecamatan Nglegok. Sedangkan kriteria eksklusinya yaitu Ibu hamil yang tidak kooperatif dan Ibu hamil yang bekerja sebagai tenaga kesehatan. Variabel independen penelitian ini adalah pendidikan kesehatan tentang tanda bahaya kehamilan dan variabel dependen penelitian ini adalah sikap tentang bahaya kehamilan. Analisis menggunakan uji statistic Wilcoxon.

\section{HASIL PENELITIAN}

Karakteristik ibu hamil di BPM Ny. FY Desa Penataran Kecamatan Nglegok Kabupaten Blitar tertera pada tabel 1 .
Tabel 1. Karakteristik Responden

\begin{tabular}{|c|c|c|c|}
\hline NO & KARAKTERISTIK & $\mathbf{f}$ & $\%$ \\
\hline \multirow[t]{4}{*}{1.} & Umur & & \\
\hline & $=20$ Tahun & 9 & 30,0 \\
\hline & 21-35 Tahun & 21 & 70,0 \\
\hline & $=36$ Tahun & - & - \\
\hline \multirow[t]{5}{*}{2.} & Pekerjaan & & \\
\hline & Pegawai Negeri Sipil & - & - \\
\hline & Swasta/W iraswasta & 3 & 10,0 \\
\hline & Petani & 2 & 6,7 \\
\hline & Ibu Rumah T angga & 25 & 83,3 \\
\hline \multirow[t]{5}{*}{3.} & Pendidikan & & \\
\hline & Dasar (SD/MI) & 2 & 6,7 \\
\hline & Menengah (SMP) & 14 & 46,7 \\
\hline & Atas (SMA/SMK/MA) & 14 & 46,7 \\
\hline & Tinggi (D3, S1, dst) & - & - \\
\hline \multirow[t]{4}{*}{4.} & Jumlah p aritas & & \\
\hline & 1 & 18 & 60,0 \\
\hline & 2 & 10 & 33,3 \\
\hline & $>2$ & 2 & 6,7 \\
\hline \multirow[t]{3}{*}{5} & Pernah dapat informasi & & \\
\hline & Ya & 14 & 46,7 \\
\hline & tidak & 16 & 53,3 \\
\hline \multirow[t]{7}{*}{6.} & Sumber informasi & & \\
\hline & Teman & - & \\
\hline & Televisi & 4 & 13,3 \\
\hline & Radio & - & - \\
\hline & Koran & - & - \\
\hline & Petugas kesehatan & 8 & 26,7 \\
\hline & internet & 2 & 6,7 \\
\hline
\end{tabular}

Tabel 2. Sikap Responden Sebelum Dan Sesudah Diberikan Pendidikan Kesehatan Tentang Tanda Bahaya Kehamilan

\begin{tabular}{cccccc}
\hline \multirow{2}{*}{ No } & \multirow{2}{*}{$\begin{array}{c}\text { Kategori } \\
\text { sikap }\end{array}$} & \multicolumn{2}{c}{ Sikap } & \multicolumn{2}{c}{ Sikap } \\
\cline { 3 - 6 } & & \multicolumn{2}{c}{ pretest } & \multicolumn{2}{c}{ post test } \\
& & f & \% & f & \% \\
\hline 1. & Positif & 15 & 50 & 30 & 100 \\
2. & Negatif & 15 & 50 & - & - \\
\hline
\end{tabular}

\section{PEMBAHASAN}

\section{Sikap ibu hamil sebelum diberikan pendidikan kesehatan (pre test)}

Berdasarkan fakta hasil penelitian sebelum diberikan pendidikan kesehatan tanda bahaya kehamilan dengan menggunakan analisis uji wilcoxon menunjukkan bahwa setengah responden (50\%) yaitu 15 orang bersikap unfavourable (negatif). Hal ini sesuai dengan penelitian yang dilakukan oleh Okki (2013) bahwa sebelum diberikan pendidikan kesehatan diketahui terdapat sebagian kecil responden bersikap kurang mendukung.

Sesuai dengan teori Widyatun,T.R, (2009) Sikap adalah keadaan mental dan saraf dari kesiapan yang 
diatur melalui pengalaman yang memberikan pengaruh dinamik atau terarah terhadap respon individu pada semua obyek dan situasi yang berkaitan dengannya. Menurut Hari Purwanto (1998) dalam Wawan dan Dewi (2010) sifat sikap terbagi atas sikap positif maupun sikap negatif.

Sikap negatif ini dipengaruhi oleh beberapa faktor yang dapat mempengaruhi. Diantaranya adalah faktor usia yaitu sebagian besar responden (70\%) berusia 21-35 tahun. Sependapat dengan teori Notoadmojo (2003) usia berpengaruh terhadap daya tangkap dan pola pikir seseorang. semakin bertambah usia seseorang maka akan semakin berkembang pula daya tangkap dan pola pikirnya sehingga pengetahuan yang diperolehnya semakin membaik. Penelitian ini sebenarnya usia ibu hamil sebagian besar sudah tergolong pada rentang usia cukup atau baik dalam kesiapan ibu dalam proses kehamilan maupun persalinan namun dalam usia ini sebagian ibu hamil masih bersikap negatif, mungkin hal ini dikarenakan fator-faktor yang kurang mendukung terjadinya sikap yang positif pada ibu saat proses kehamilan berlangsung.

Berdasarkan penelitian didapatkan bahwa sebagian besar (60\%) jumlah paritas dari ibu hamil adalah 1 anak. Paritas menunjukkan pengalaman dalam kehamilan dan persalinan. Orang yang pernah hamil akan mempunyai pengetahuan tentang kehamilan yang baik dibandingkan yang belum pernah mengalami kehamilan. Pengertian ini diartikan bahwa pengalaman merupakan sumber pengetahuan. Pengalaman pribadi juga dapat digunakan sebagai upaya untuk memperoleh kebenaran pengetahuan, dan bisa menjadi dasar pembentukan sikap, dimana pengalaman pribadi harus meninggalkan kesan yang kuat, karena sikap akan lebih mudah terbentuk apabila pengalaman pribadi tersebut dapat terjadi dalam situasi yang melibatkan faktor emosional (Azwar, 2009). sebagian besar ibu hamil memiliki jumlah paritas yaitu 1 anak. Disimpulkan bahwa responden dalam penelitian ini tingkat pengalamannya masih rendah. Rendahnya pengalaman ibu menimbulkan minat untuk mencari tahu tentang tanda bahaya kehamilan juga rendah.

Berdasarkan penelitian didapatkan pula bahwa sebagian besar ibu hamil $(53,3 \%)$ yaitu 16 orang belum mendapatkan informasi. Dengan gambaran tersebut, maka mempengaruhi pengetahuan yang dimiliki ibu hamil kurang. Yang mana menurut Notoatmodjo (2007), yaitu. dengan mendapat informasi dapat menambah wawasan seseorang, namun dalam penelitian ini responden sebagian besar tidak pernah mendapatkan informasi sehingga sebagian ibu hamil pengetahuan terhadap tanda bahaya kehamilan masih kurang dan dengan pengetahuan yang masih kurang ini sikap dari ibu hamil akan tanda bahaya kehamilan termasuk dalam kategori sikap unfavourable (negatif).

\section{Sikap ibu hamil sebelum diberikan pendidikan kesehatan (pre test)}

Berdasarkan fakta hasil penelitian setelah diberikan pendidikan kesehatan tanda bahaya kehamilan dengan menggunakan analisis uji wilcoxon menunjukkan bahwa seluruh responden (100\%) yaitu 30 orang bersikap favourable (positif). Sependapat dengan teori Notoatmodjo (2003) terhadap tujuan dari pendidikan kesehatan itu sendiri. Tujuan pendidikan kesehatan adalah terjadinya perubahan dalam membina individu, keluarga atau masyarakat dalam membina dan memelihara perilaku dan lingkungan sehat serta berperan aktif dalam upaya mewujudkan derajat kesehatn yang optimal. Sesuai dengan fakta dan teori diatas, peneliti berpendapat bahwa setelah diberikan pendidikan kesehatan tentang tanda bahaya kehamilan seluruh responden (100\%) bersikap favourable (positif).

Sikap postif ini dipengaruhi beberapa faktor salah satunya adalah usia. Dari hasil penelitian menunjukkan bahwa usia sebagian besar responden (70\%) yaitu berusia 21-35 tahun. sependapat dengan Notoadmojo (2003) usia berpengaruh terhadap daya tangkap dan pola pikir seseorang. semakin bertambah usia seseorang maka akan semakin berkembang pula daya tangkap dan pola pikirnya sehingga pengetahuan yang diperolehnya semakin membaik. Sesuai dengan fakta diatas peneliti berpendapat bahwa dengan semakin matangnya umur responden akan mampu melakukan sikap yang baik terhadap kehamilannya sehingga tanda bahaya kehamilan dapat diketahui secara dini dan komplikasi selama kehamilan juga dapat dihindari.

Penelitian juga menunjukkan bahwa hampir sebagian responden $(46,7 \%)$ memiliki tingkat pendidikan menengah atas atau SMA. Hal ini menunjukkan tingkat pendidikan responden cukup baik. Tingkat pendidikan seseorang sangat berpengaruh pada sikap seseorang. Hal ini sesuai dengan teori Notoatmodjo (2007) yaitu pendidikan adalah suatu usaha untuk mengembangkan kepribadian dan kemampuan di dalam dan di luar sekolah dan berlangsung seumur hidup. Pendidikan mempengaruhi 
proses belajar, makin tinggi pendidikan seseorang makin mudah seorang tersebut untuk menerima informasi. Dengan pendidikan SMA ini ibu hamil akan lebih mudah dalam mengakses informasi tentang tanda bahaya kehamilan. hal ini akan berpengaruh terhadap pengetahuan.

Berdasarkan penelitian didapatkan pula sebagian besar responden $(83,3 \%)$ adalah ibu rumah tangga atau tidak bekerja. Adapun faktor pekerjaan menujukkan seberapa banyak waktu yang dimiliki untuk mencari informasi kesehatan. Sebagian besar ibu hamil tidak bekerja yang artinya mereka memiliki waktu yang cukup banyak yang dapat digunakan untuk mencari informasi seputar kehamilan sehingga pengetahuan akan menjadi baik. Dengan demikian pada dasarnya pendidikan dan pekerjaan meningkatkan pengaruh faktor informasi terhadap pengetahuan.

\section{Pengaruh pendidikan kesehatan tentang tanda bahaya kehamilan terhadap sikap ibu hamil}

Berdasarkan hasil penelitian menunjukkan bahwa terdapat perbedaan sikap terhadap tanda bahaya kehamilan saat sebelum dan sesudah diberikan pendidikan kesehatan. Dari hasil analisi menggunakan Uji Wilcoxon melalui komputerisasi diperoleh $\mathrm{p}$ value $(0,0001)<\alpha=0,05$ yang menunjukkan bahwa $\mathrm{H} 1$ diterima, yang artinya terdapat pengaruh pendidikan kesehatan tanda bahaya kehamilan terhadap sikap ibu hamil tentang tanda bahaya kehamilan di BPM Ny. Fy Desa Penataran Kecamatan Nglegok Kabupaten Blitar. Hal ini sesuai dengan penelitian Hastuti (2011) pengaruh penyuluhan tanda bahaya kehamilan terhadap sikap ibu hamil dalam menghadapi tanda bahaya kehamilan di pondok bersalin Puri Husada Menggung Ngemplak Boyolali terdapat peningkatan skor sikap setelah diberi pendidikan kesehatan.

Berdasarkan hasil penelitian menunjukkan bahwa setelah diberikan pendidikan kesehatan tentang tanda bahaya kehamilan seluruh responden (100\%) yaitu 30 orang bersikap favourable (positif). Hal ini terlihat dari antusias responden dalam menjawab kuesioner dan telah mendapatkan pendidikan kesehatan tentang tanda bahaya kehamilan. Lawrence Green (1984) dalam (Notoadmodjo, 2010: 24) merumuskan definisi sebagai berikut: "promosi kesehatan adalah segala bentuk kombinasi pendidikan kesehatan dan intervensi yang terkait dengan ekonomi, politik, dan organisasi, yang dirancang untuk memudahkan perubahan perilaku dan lingkungan yang kondusif bagi kesehatan".
Menurut Notoadmojo (2007) dalam perkembangannya, teori Bloom untuk pengukuran sikap terbagai beberapa tingkatan yaitu: Menerima (Receiving), Merespon (Responding), Menghargai (Valuing), Bertanggung jawab (Responsible). Melalui upaya pendidkan kesehatan ini maka dapat dilakukan penyadaran tentang betapa pentingnya mengetahui tanda bahaya kehamilan guna untuk menentukan sikap yang positif terhadap tanda bahaya kehamilan dan juga untuk mencegah sedini mungkin terhadap terjadinya komplikasi-komplikasi selama proses kehamilan berlangsung. Sehingga dapat disimpulkan bahwa pendidikan kesehatan tanda bahaya kehamilan ini sangat berpengaruh terhadap sikap ibu hamil di BPM Ny. Fy Desa Penataran Kecamatan Nglegok Kabupaten Blitar.

\section{SIMPULAN DAN SARAN}

\section{Simpulan}

Hasil penelitian menunjukkan bahwa (1) Sikap ibu hamil tentang bahaya kehamilan sebelum diberikan pendidikan kesehatan tanda bahaya kehamilan yaitu setengah responden bersikap unfavourable (negatif) (2) Sikap ibu hamil tentang bahaya kehamilan sesudah diberikan pendidikan kesehatan tanda bahaya kehamilan keseluruhan bersikap favourable (positif) (3) Ada pengaruh pemberian pendidikan kesehatan tanda bahaya kehamilan terhadap sikap ibu hamil tentang tanda bahaya kehamilan di BPM Ny. Fy Desa Penataran Kecamatan Nglegok Kabupaten Blitar.

\section{Saran}

Bagi Peneliti selanjutnya untuk memperbarui materi dalam memberikan informasi tentang tanda bahaya kehamilan serta mengembangkan penelitian dengan menggunakan metode pembelajaran yang baru dan dengan desain penelitian yang berbeda.

\section{DAFTAR RUJUKAN}

Azwar, S. 2009. Sikap manusia teori dan pengukurannya. Yogyakarta: Pustaka Pelajar.

Dharma, K.K. 2011. Metodologi Penelitian Keperawatan: Panduan Melaksanakan dan Menerapkan Hasil Penelitian. Jakarta: Trans Info Media.

Hidayat, A. Aziz, Alimul. 2011. Metode Penelitian Keperawatan Dan Teknik Analisa Data. Jakarta: Salemba Medika.

Hidayati, R. 2009. Asuhan Keperawatan pada Kehamilan Fisiologis dan Patologis. Jakarta: Salemba Medika. 
Manuaba Ida Bagus. 2006. Ilmu Kebidanan Penyakit Kandungan Dan Keluarga Berencana. Jakarta: EGC.

Notoadmojo 2010. Promosi Kesehatan Teori Dan Aplikasi. Jakarta: Rineka Cipta.

Nursalam. 2013. Metodologi Penelitian Ilmu Keperawatan: pendekatan praktis. Jakarta: Salemba Medika.
Wawan, A.D. 2010. Teori Dan Pengukuran Sikap, Dan Perilaku Manusia. Yogyakarta: Nuha Medika.

Widyatun, T.R. 2009. Ilmu Perilaku. Jakarta: CV Agung Seto.

Wiknjosastro, H. 2010. Ilmu Kebidanan. Jakarta: Yayasan Bina Pustaka Sarwono Prawiroharjo. 